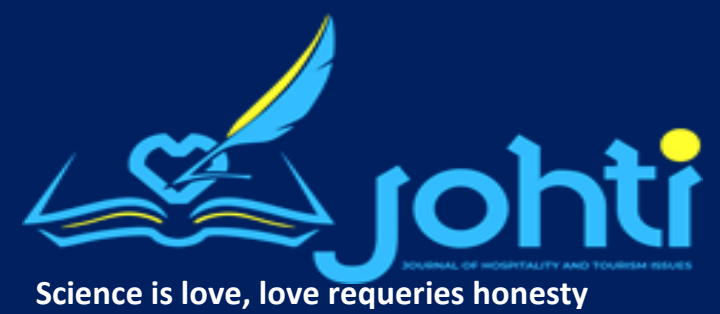

Science is love, love requeries honesty
Journal of Hospitality and Tourism Issues

$3(1), 37-54$

Makale Türü/Article Type

Araştırma Makalesi/ Research Article

Geliş/Kabul-Received/ Accepted

22/04/2021- 17/05/2021

\title{
Kayseri Hürmetçi Sazlığının Ornito Turizm Potansiyelinin Değerlendirilmesi
}

\author{
Osman ÖZER ${ }^{1}$
}

Özet

Özel ilgi turizminin bir dalı olan eko turizme ilgi duyan turistlerin çoğunlukla kuş gözlemciliğine diğer isimleri ile ornito turizm ve avi turizme yöneldikleri görülmektedir. Dünya olduğu gibi, Türkiye'de de kuş gözlemciliği talebi hızlı bir ivme kazanmışırı. Kayseri ili sınırları içerisinde yer alan Hürmetçi Sazlığı içerisinde barındırdığı 136 çeşit farklı ornito faunası ve Sultan Sazlığına yakınlığıyla ornito turizm açısından potansiyeli değerlendirilmesi gereken, korunan sulak alanlardan biridir. Çalışmada konumu ve içinde bulundurduğu biyoçeşitlilik bakımından zenginliği olan Hürmetçi Sazlığının kuş gözlemciliği açısından potansiyelinin değerlendirilmesi amaçlanmıştır. Bu çalışmada; literatür taramasıyla ile alan gezisi yöntemi kullanılarak, öncelikle ornito turizmi kavramı irdelenip, devamında Hürmetçi Sazlığının ornito turizm açısından sosyoekonomik potansiyeli değerlendirilmiştir. Alan gezileri sırasında ilkbahar dönemimde bölgede çok sayıda kuşun kuluçkaya yattığı ve yavrularını çıkarttığı gözlemlenmiştir. Ayrıca kış döneminde günlük değişimler olmasıyla beraber bölgedeki kuş popülasyonun göç yolunda bulunması nedeniyle arttı̆̆ gözlemlenmiştir. Mevsimsel farklılıkların ornito turizmi için pozitif yönde talep edilebilirliğini artırdığı savı değerlendirilerek elde edilen bulgular ışığında sonuç kısmı oluşturulmuş, bölgenin korunması ve kalkınması için yapılandırıcı önerilerde bulunulmuştur.

Anahtar Kelimeler: Ornito Turizm, Kuş Gözlemciliği, Avi Turizm, Kayseri, Hürmetçi Sazlığ1

JEL Kodu/Code: L83, Q26

\section{Evaluation of Kayseri Hürmetçi Reeds' Ornitho Tourism Potential}

\section{Abstract}

It is observed that tourists who are interested in eco tourism, which is a branch of special interest tourism, mostly turn to bird watching, ornitho tourism and aviation tourism. As in the world, the demand for bird watching has gained rapid momentum in Turkey. Hürmetçi Marshes, located in the province of Kayseri, is one of the protected wetlands with 136 different ornitho fauna and its proximity to the Sultan Marshes and its potential in terms of ornitho tourism. In the study, it was aimed to evaluate the potential of Hürmetçi Marshes in terms of bird watching, which is rich in terms of its location and biodiversity. In this study; Firstly, the concept of ornitho tourism was examined and the socio-economic potential of Hürmetçi Reeds in terms of ornitho tourism was evaluated. During my field trips, it was observed that in the spring period, many birds in the region brood and hatch their babies. In addition, it has been observed that the bird population in the region has increased due to the migration route with the daily changes in the winter period. Considering the argument that seasonal differences increase positively demand for ornitho tourism, a conclusion part was created in the light of the findings, and constructive suggestions were made for the protection and development of the region.

Key Words: Ornitho Tourism, Bird Watching, Avi Tourism, Kayseri, Hürmetçi Marshes

Referans/Citation: Özer, O. (2021). Kayseri hürmetçi sazlığının ornito turizm potansiyelinin değerlendirilmesi, Journal of Hospitality and Tourism Issues, Vol. 3, No.1, 37-54.

\footnotetext{
${ }^{1}$ Gastronomi Uzmanı, Kaski Genel Müdürlüğü, Kayseri, Turkey, osman-ozer@ hotmail.co.uk. Orcid ID: 0000-0001-85430664
} 


\section{GİRIŞ}

Turizm endüstrisi devlet ekonomisinin ayrılmaz bir parçası ve ülkenin sosyal, ekonomik kalkınması için çok önemli olduğu kabul edilmektedir (Asan vd., 2015: 631). Öncelikle ekonomik gelir elde etmeyi hedefleyen turizm, kitle turizmi ile kaynakların düzensiz şekilde kullanılmasına neden olmuştur. Kitle turizminin oluşturduğu deformasyondan ve dünyadaki sosyo-ekonomik gelişmelere bağlı olarak her alanda olduğu gibi, turizm endüstrisinde de önemli değişimler gözlenmektedir. Sınırsız büyüyen, standartlaştırılmış, kalıplaştırılmış turizm ürünü ve hizmeti yerine doğaya ve çevreye daha duyarlı turizm türlerine eğilim artmaktadır (Sert \& Arslan, 2019: 2105). Turizm endüstrisi aktörlerinin ve destinasyonlarının rekabetçi kalabilmek için bu duruma ayak uydurması gerektiği görülmektedir (Pekin, 2011; Sert \& Arslan, 2019: 2105).

Farklı sosyo-kültürel yapıya ve beklentilere sahip olan turistlerin taleplerine doğrultusunda alternatif turizm kavramı ortaya çıkmıştır. Doğal kaynakların korunarak çevrenin tahrip edilmemesi ve yöre halkının kontrollü şekilde turizm faaliyetleri içerisine çekilmesi yönüyle alternatif olarak geliştirilen bu kavram ile turizmin on iki aya yayılması ve turizm gelirinin arttırılması istenmektedir (Topay \& Parladır, 2015: 301). Alternatif turizm optimum kârlılığı, uzun vadeli sürdürülebilir gelişimi, çevreyi korumayı ve çevre ile bütünleşmeyi sağlamaktadır (Sezgin \& Ünüvar, 2009: 396; Asan vd., 2018: 632).

Alternatif turizm gibi özel ilgi turizmi de geleneksel kitle turizminin olumsuz sonuçlarından rahatsız olan turistlerin alternatifler aramaları ve zevklerine yönelik hareketleri sonucu 70'li yıllarda gündeme gelmeye başlamıştır. Devamında 80'li yıllar da ise büyük bir gelişme gösteren geniş kapsamlı bir turizm çeşidi olmuştur (Gülbahar, 2009: 163; Asan vd., 2018: 632). Bu turizm türü bireylerin rutin işleri dışında zevkleri ve uğraş için yaptıkları faaliyet ya da aktiviteler olarak nitelendirilebilmektedir (Bahçe, 2013: 129). Sadece boş zamanlar için değerlendirilen aktiviteler her zaman özel ilgi turizmi olarak adlandırılmamaktadır; bu tanımlamanın yapılabilmesi için iki faktör dikkate alınmaktadır. Birincisi; özel ilgiye yönelik özel bir zamanın ayrılması, ikincisi tatminle sonuçlanan bir ticari faaliyet olması gerekliliğidir (Trauer, 2006: 186 - 187; Asan vd, 2018: 632).

Sürdürebilirlik, çevre ve doğa temelli turizm çeşidi olan eko turizm içerisinde hem alternatifliği hem de özel ilgiyi barındırabilmektedir. Eko turizmin ve özel ilginin bir arada yapılabildiği ornito turizmi (Kuş Gözlem) dünya çapında pek çok turizm aktivitesinin varlığına rağmen son yılların en fazla rağbet gören turizm aktivitesi olmaya başlamıştır (Sevindi, 2013: 64). Genelde az gelişmiş ülkelerde tabiatın bozulmamasından dolayı yaygın olarak yapılan ornito turizmi; gelişmekte olan ülkeler dahil olmak üzere tüm dünyada hızla gelişen bu turizm türü Amerika'da da en hızlı büyüyen açık hava aktivitesi olarak görülmektedir (Responsible Travel, 2021).

Kuş gözlemciliği, kuşları doğal ortamlarında gözlemleme ve tanımlama faaliyeti olduğu gibi fiziksel aktiviteler içermesi nedeniyle doğayı kuşların dünyasından tanımayı sağlayan bir gözlem sporudur. Kuş gözlemcileri, eğitimli ve yüksek gelir seviyesine sahip eko-turist grubunun önemli bir bölümünü oluşturmalarından dolayı, eko-turizm gelirinin en iyi kaynaklarından biridir (Ceballos-Lascurain, 1996; Cordell \& Herbert, 2002; Şekercioğlu, 2002: 282).

Dünyadaki gelişmelere paralel olarak Türkiye'de kuş gözlemciliğine olan ilginin hızla artmakta olduğu görülmektedir. Örneğin Manyas Kuş Cennetinden yıllık 103 milyon dolar gelir elde edilebileceği ileri sürülmüştür (Gürlük \& Rehber, 2008; Sert \& Arslan, 2019: 2105). Bu öngörünün sonrasında ise 17-22 Mayıs 2019 tarihleri arasında Mersin Çamlıyayla'da Doğa Derneği ve Birdlife International'ın desteği ile organize edilen 19. Kuş Konferansı'na yurt dışından ve ülkemizden yüzlerce ilgili kişi katılmıştır. Bu da kuş gözlemciliğine olan ilginin günden güne arttığını göstermektedir (Çorba, 2019: 20). Sadece kuş 
gözlemciliği konferansı yapılması; otel konaklaması, konferans salonu bedeli ve gastronomi harcamaları gibi ekonomik girdiler ile turizm gelirlerine katkıda bulunmaktadır.

Türkiye sahip olduğu ekosistem ve coğrafi yapısından dolayı 487 kuş türüyle Avrupa'nın kuş gözlemcilik potansiyeli en yüksek ülkelerinden biridir (Özkazanç \& Özay, 2019: 79). Tarım ve Orman Bakanlığının verilerine göre zengin sulak alanlara sahip olması ve kuş göç yolları üzerinde bulunması ile Türkiye'de gözlemlenen toplam kuş türlerinin sayısı Avrupa'da gözlemlenen kuş türleri sayısı kadar olduğu belirtilmektedir (Tarım \& Orman Bakanlığı, 2021). Bu kadar zengin bir ekosisteme ve dört önemli kuş göç yolunun ikisinin Türkiye'den geçmesine rağmen, var olan doğal kaynakların ornito turizm açısından verimli bir biçimde değerlendirilemediği söylemek mümkündür. Eko turizmin en fazla gelir getiren alt dallarından biri olan kuş gözlemciliği turizminden elde edilen gelirlerin arttırılması ve var olan kaynakların optimum fayda sağlayacak şekilde kullanılması açısından önemi büyüktür.

$\mathrm{Bu}$ araştırmada Türkiye'nin Manyas Kuş Cennetinden sonra ikinci büyük kuş cenneti olan Sultan Sazlığına (Akmeşe \& Ilgaz, 2019: 178) yakınlığıyla beraber, 2004 yılında 9 Ramsar (su kuşları yaşama ortamı olarak uluslararası öneme sahip sulak alanlar hakkında sözleşme) kriterinden birini taşıdığı için ulusal öneme haiz sulak alan olarak tanımlanan Hürmetçi Sazlığının ornito turizmi açısından potansiyelinin değerlendirilmesi amaçlanmıştır.

\section{KAVRAMSAL ÇERÇEVE}

Özel ilgi turistleri; modern çağın gelişi, teknolojinin gelişmesi ve geleneksel kitle turizminden sıkılarak özellikle bireysel veya az sayıda insanla etkileşimde olacakları turizm çeşitlerini tercih etmektedirler. Turistlerin farklı arayışlar içerisine girerek özel ilgi turizmine yöneldikleri görülmektedir. Bu arayışlar arasında ornito turizm doğaya dayalı turizm türlerinden biri olarak özel ilgi turizminin içerisinde değerlendirilmektedir. Ornito turizmin oluşabilmesi için öncelikle tahrip edilmemiş tabiat, ornito faunası ve doğal hayatın bilincinde olan kuş gözlemcilerinin bir arada olması gerekmektedir.

Turizm literatüründe kuş gözlemciliği motivasyonuyla yapılan seyahatlerin kimi kaynaklarda ornitotourism, kimilerinde ise "avi tourism” olarak isimlendirildiği görülmektedir. Bu kavramlar Türkçe'de de ornito turizm ya da avi turizm olarak kullanılmaktadır. Avi turizm faaliyetine katılan bireylere ise avi turist denilmektedir (Çakıcı \& Harman, 2006: 162). Avi turistlerin kuş gözlem alanlarına seyahat etmeleri ve o bölgelerde konaklama yapmaları nedeniyle önemli bir turizm piyasası oluşmaktadır (Sop, 2015: 544).

Kuş gözlemciliği, yabani kuşların doğal habitatlarında gözlemlenmesi ve tanımlanmasını temel alan, kimileri için hobi olarak ilgilenilen, kimilerinin ise (ornitologlar) bilimsel amaçlar ile kullandığı bir uğraştır. Kuş gözlemciliği "kuşları kendi yaşam alanlarında gözlemleme ve tanımlama faaliyeti” olarak da tanımlanmaktadır (Ceballos-Lascurain, 1996; Cordell \& Herbert, 2002; Şekercioğlu, 2002: 283; Çorba, 2019: 17).

Kuş gözlemciliğinde; bilgili bir rehber, bir kuş gözlem turunun başarısı için anahtardır. Büyük beklentileri olan kuş gözlemcileri için bir rehber tutmak çok faydalıdır çünkü bu daha nadir ve yerel türleri görme şansını arttırır, yerel ekonomiye katkıda bulunur ve yerel insanları kuşları korumaya teşvik eder. Kuş gözlemcileri genellikle yerel rehberleri tercih etmeleri sebebiyle faaliyetlerini gerçekleştirme esnasında yöre halkıyla olan etkileşimleri artmaktadır. Bölgede kuş gözlemciliğinin yapılması nedeniyle yerel halkın gelir elde etmesi durumunda, bölgeyi ziyaret eden kuş gözlemcileri yönelik iyi bir izlenim ortaya çıkmaktadır (Şekercioğlu, 2002: 284; Çakıcı \& Harman, 2006: 162).

Kuş gözlemciliğinin sosyo-kültürel ve ekonomik olarak faydaları şu şekilde sıralanmıştır (Pekçetinöz, 2006: 17). 
Eğlence yönü: Doğada gözlem yaparak eşsiz güzelliğiyle bağlantı kurulmasıdır.

Tatmin yönü: Avcılığa benzer bir tutkuya sahip olunan kuş gözlemciliği, avlanırken içgüdüsel hazzı ve tatmini yaşatmaktadır.

Sağlık yönü: Günümüzde kuş gözlemciliği toplu halde, rahatlama ve dinginlik açısından en güvenli sporlardan birisidir. Erken kalkmak gereklidir. Bedeni çok yormadan kısa yürüyüşler yapılmaktadır.

Ailevi yönü: Birçok nesli birleştirebilmektedir. Aileler veya akrabaların yaşamları boyunca kuşlar ve doğa hakkında edindikleri bilgi birikimlerini nesilden nesle aktarabilmektedirler.

Arkadaşlık yönü: Toplu halde yapıldığında, sosyal aktivite olarak kuş gözlemciliği idealdir. Özellikle kertikçiler yalnız olarak kuş gözlemini yapmaktadırlar. Genellikle her kuş gözlem grubunun bir kulübü olmaktadır. Bu kulüplerde bilgilerini paylaşmak kuş gözlemcileri mutlu etmektedir.

Bağımsızlık yönü: Bağımsız bir şekilde yapılabilen kuş gözlemciliği aynı zamanda bireysel yapılan ideal bir spordur. Bireysel olarak yapılan gözlemlerde ayrı bir tatmin olabilmektedir. Ornito turizmi bireysel, grup ve aile ile yapılan bir aktivite olduğu için her kesimden turiste hitap edebilmektedir.

Türkiye'de yapılan kuş gözlem çalışmaları 19. yüzyılda yurtdışından gelen Alman ve İngiliz doğa bilimcileri ve gözlemcilerinin gezi notlarıyla başlamıştır. İç Anadolu' da ornitolojiyle ilgili ilk geniş çaplı araştırma gezilerini İngiliz Zoolog Charles G. Danford başlatmıştır. Bu gezilerden ilki 1875 yılında İzmir'den Mersin'e geçerek, Toroslar üstünden Erciyes Dağı, Kayseri ve Merzifon'u geçip Samsun'da sona ermiştir. Anadolu'nun güneyinden kuzeyine kadar giden bu gezilerde toplam 185 kuş türü tespit edilmiştir. Danford bu gezilerinde "Dağ bölgesinin ornito faunasının, Avrupa'nın karakteristik türlerini yansıttığı” kanısına varmıştır (Arslangündoğdu, 2005; Aslan, 2019: 6). Bir diğer kaynakta ise; Dünya tarihinde kuş gözlemciliği, 18. yüzyıl sonlarında tüy, yumurta gibi koleksiyonculuk amacı ile başlanmış, 19. yüzyılın sonlarında ise koruma amaçlı bir hale dönüşmüştür. Türkiye'de bilimsel anlamda kuş gözlemciliğinin tarihçesine bakıldığında ise, ornitolojik çalışmaların Hitler rejiminden kaçarak 1930’lu yılların ikinci yarısında Türkiye'ye sığınan Alman bilim adamı zoolog Prof. Dr. Curt Kosswig'in İstanbul Üniversitesi Fen Fakültesinde ders vermeye başlaması ve asistanlarıyla birlikte Türkiye'nin hemen her köşesine gidip, oralardaki faunaya ait ilk kayıtları tutması ile hız kazandığı bildirilmektedir (Kandir \& Erturhan 2015: 16).

Kuşlar ve gözlemciliği ile farklı çalışmalar yapılmaktadır. Bu çalışmaları incelemek daha kesin ve doğru bilgiye ulaşmanın yoludur. Dünya Yaban Hayatı Formu (WWF) tarafından 2019 yılında yayımlanan 2014-2017 yıllarında yapılan Türkiye Üreyen Kuş Atlası araştırması ile Türkiye'de hangi türlerin geçmişten günümüzde üremeye devam ettiği tespit edilmiştir. Bu sayede türlerin yayılış haritaları kuş gözlem uzmanları tarafından oluşturulmuştur. Uzmanlar Türkiye'de düzenli görülen 400 türün 313 'ünün üremeye devam ettiği tespit edilmişlerdir. Sayısal veriler Türkiye'deki zengin biyoçeşitlilik oranını göstermektedir. Farklı coğrafi bölgelerin habitatlarındaki çeşitliliğin bir göstergesidir. WWF tarafından yapılan çalışmada üç önemli türün artık Türkiye'de üremediği ve sınırları içindeki üreyen popülasyonlarının zamanla yok olduğu tespit edilmiştir. Bu türler; Göksu Deltası'nda geçmişte üreyen yaz ördeği (Marmaronetta angustirostris), Doğu Anadolu'da dört farklı sulak alanda ürediği kayıt altına alınmış telli turna (Grus virgo) ve Doğu Anadolu'nun yüksek göllerinde yuvalamış kadife ördeğin (Melanitta fusca) bir üreme faaliyeti tespit edilemediği raporda belirtilmiştir. Avrupa'da, belli bir oranının Avrupa Birliği oluşumu nedeniyle, tarım ve ormancılık politikalarında yaşanan değişiklikler sonucunda bazı yaygın türlerin popülasyonları ciddi oranda azaldığı gözlemlenmiştir. Avrupa geleninde azalmış olan üveyik (Streptopelia turtur), tarlakuşu (Alauda arvensis), kızıl sırtlı örümcekkuşu (Lanius collurio) ve kirazkuşu (Emberiza hortulana) gibi türlerin günümüzde Türkiye'deki popülasyonlarının 
yaygın ve yüksek oranda üremekte olduğu tespit edilmiştir. Türkiye'nin birçok bölgesinde geleneksel üretim sistemlerinin devam etmesi, tarla kenarlarında yetişen yabani otların varlığı, engebeli ve kayalık arazide korunan yaşam alanları bu türlerin korunmasının nedeni olabileceği düşünülmektedir (Kustr, 2021).

Dünyanın önemli kuş göç yolu üzerinde yer alan Türkiye kuş türleri bakımından oldukça zengindir. Bu göç yolu, Rusya’nın kuzeyinden başlayıp Karadeniz, Boğazlar ve Anadolu’yu izleyerek doğu Afrika'ya uzanan göç yoludur (Erdoğan vd., 2010: 48). Avrupa kıtasında 430’u üremek üzere 455 kuş türü yaşarken Türkiye'de ise 184 adet Önemli Kuş Alanı'nda (ÖKA) bu sayı göçmen ve yerli kuşlarla birlikte 502 (437'si düzenli, 65'i rastlantısal)'dir (Kiziroğlu, 2008: 48; Tunç, 2018: 2). Kuş çeşitliliğinin bu denli fazla olan bir coğrafya sahip olan Türkiye'de ornito turizminin geleceği çok aydınlıktır. Hürmetçi sazlığı da ornito turizmi için incelenmeye ve turizme kazandırılmaya değer bir sulak alandır.

\section{YÖNTEM}

\subsection{Araştırmanın Amacı ve Önemi}

Çalışmada Kayseri ilinde Hacılar ve İncesu ilçesine bağlı olan, merkezin $13 \mathrm{~km}$ güneybatısında ve Hürmetçi ile Karpuzsekisi mahalleleri sınırları içerisinde bulunan, güneyinde Erciyes Dağ1, güneydoğusunda ise Sultan Sazlığı yer alan Hürmetçi Sazlığının ornito turizm potansiyelinin incelenmesi amaçlanmıştır. Ayrıca bu araştırmanın; bölgenin potansiyelinin güçlü ve zayıf yönlerini, tehdit ve firsatları ortaya çıkarması bakımından önem taşıyacağı öngörülmektedir. Araştırma sonuçları ile birlikte; bölgeye ait zayıf yönleri güçlendirme, tehditleri ortadan kaldırma ve firsatları fark edip bunları avantaja dönüştürme şansı sunacaktır (Akmeşe \& Ilgaz, 2019: 180).

\subsection{Veri Toplama Yöntemi}

Araştırma kapsamında veri toplama yöntemi olarak alan gezisi ve literatür araştırması yapılmıştır. Alan gezisinde genel olarak öncelikle yerel halkın turizm ve sazlık hakkındaki bilinci gözlemlenmiştir. Sonrasında Hürmetçi Sazlığının güçlü yönleri, zayıf yönleri, fırsatları tehditler ve bulunduğu hakkındaki durum gözlemlenmiştir. Ayrıca sazlıktaki kuşların faunası ve dönemsel hareketleri de takip edilmiştir. Yapılan gözlemlemeler not defterine not alınarak yazılı metne dönüştürülmüştür. Bu kapsamda araştırmada elde edilen bilgiler doğrultusunda Hürmetçi Sazlığının mevcut durumu ve turizm potansiyeli kuş gözlemciliği turizmi bakımından ortaya çıkartılmaya çalışılmıştır.

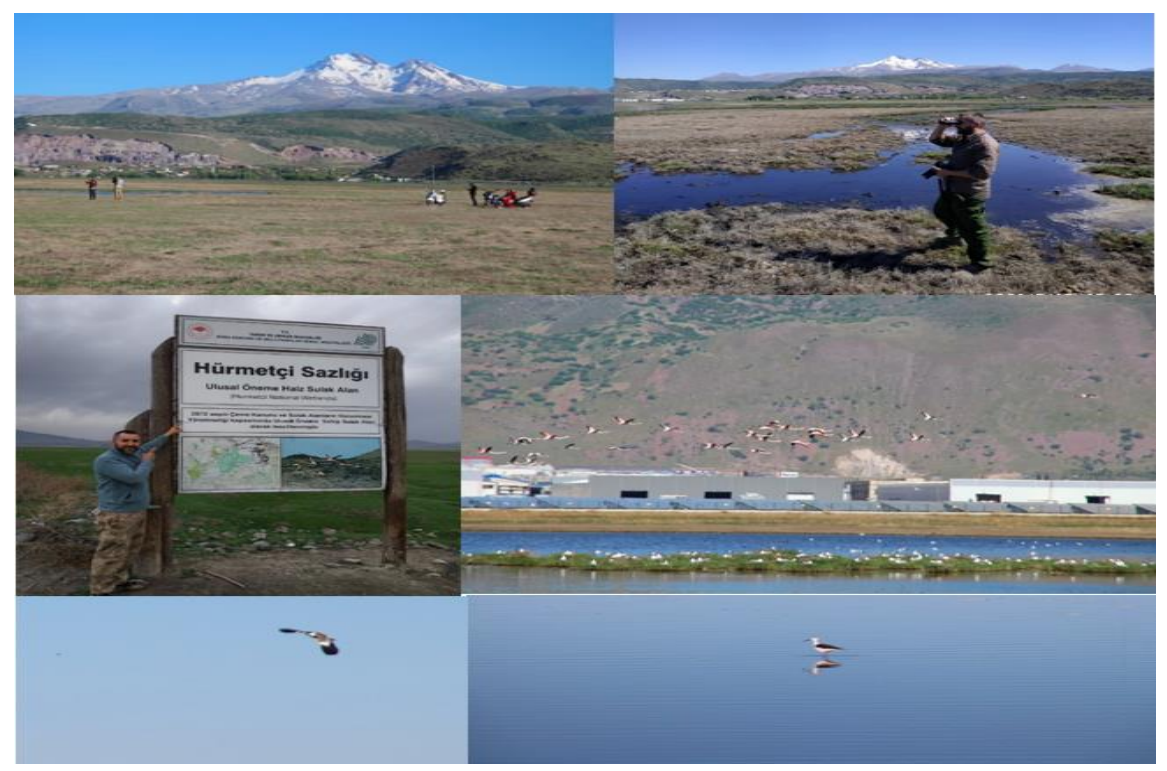

Fotoğraf 1-2-3-4-5-6. Hürmetçi Sazlığı alan gezisi ve kuş gözlemciliği (Özer, 2021). 


\section{BULGULAR}

Alan gezileri ve literatür araştırmaları ışığında Hürmetçi Sazlığının kuş gözlemciliği turizmi açısından potansiyelinin değerlendirilmesinde; literatür kısmında ornito turizm kavramı incelenmiş, bulgular bölümünde Hürmetçi Sazlığının coğrafi konumu ve bölgenin turizm açısından güçlü ve zayıf yönleri, tehditler ve firsatlar ortaya koyulmaya çalışılmıştır.

\subsection{Araştırma Alanı/Sahası Hürmetçi Sazlığının Coğrafyası}

Araştırma sahası Hürmetçi Sazlığı (Karasaz) mevsimsel yağışlar ve Erciyes Dağı'ndaki karların erimesi ile suyla dolmaktadır. Kayseri şehir merkezinin 13 kilometre güneybatısına, Hacılar ve İncesu ilçelerinin sınırları içerisin de yer almaktadır. Kuzey batısında Saraycık, Güzeybatısında Örenşehir, güneyinde Bahçelievler ve Dokuzpınar, Güneybatısında Hürmetci, Karpuzsekisi ve Karpuzseki, batısında Gelbula, Kuzeybatısında Organize Sanayi mahalleri (Şekil:1) arasında kalan ekosistem, 2004 yılında 9 Ramsar kriterinden birini taşıdığı için Tarım ve Orman Bakanlığı (önceki adı Çevre ve Orman Bakanlığı) tarafından ulusal öneme haiz sulak alan olarak tanımlanmıştır. Deniz seviyesinden yaklaşık 1073 metre yükseklikte yer alan Hürmetçi Sazlığı; Avrupa, Asya ve Afrika kıtalarından geçen göç rotası üzerinde bulunmaktadır (Kültür \& Turizm Bakanlığı, 2021).

Sulak Alan Adı: Hürmetçi Sazlığı İı: Kayseri İlçe: İncesu, Hacılar Havza: Kızılırmak Havzası

Sulak Alan Büyüklüğü (ha): 3100,00 Bölge: DKMP 7.Bölge (Adana)

Statüsü: Ulusal Öneme Haiz Sulak Alanlar Komplekste Bulunan Sulak Alan Sayısı: 1

Tescil Tarihi: 8.4.2015 Tescil Alan Büyüklüğü (ha): 15713,00

Yönetim Plan Durumu: Var 6.6.2018 (Tarım \& Orman Bakanlığı, 2021)

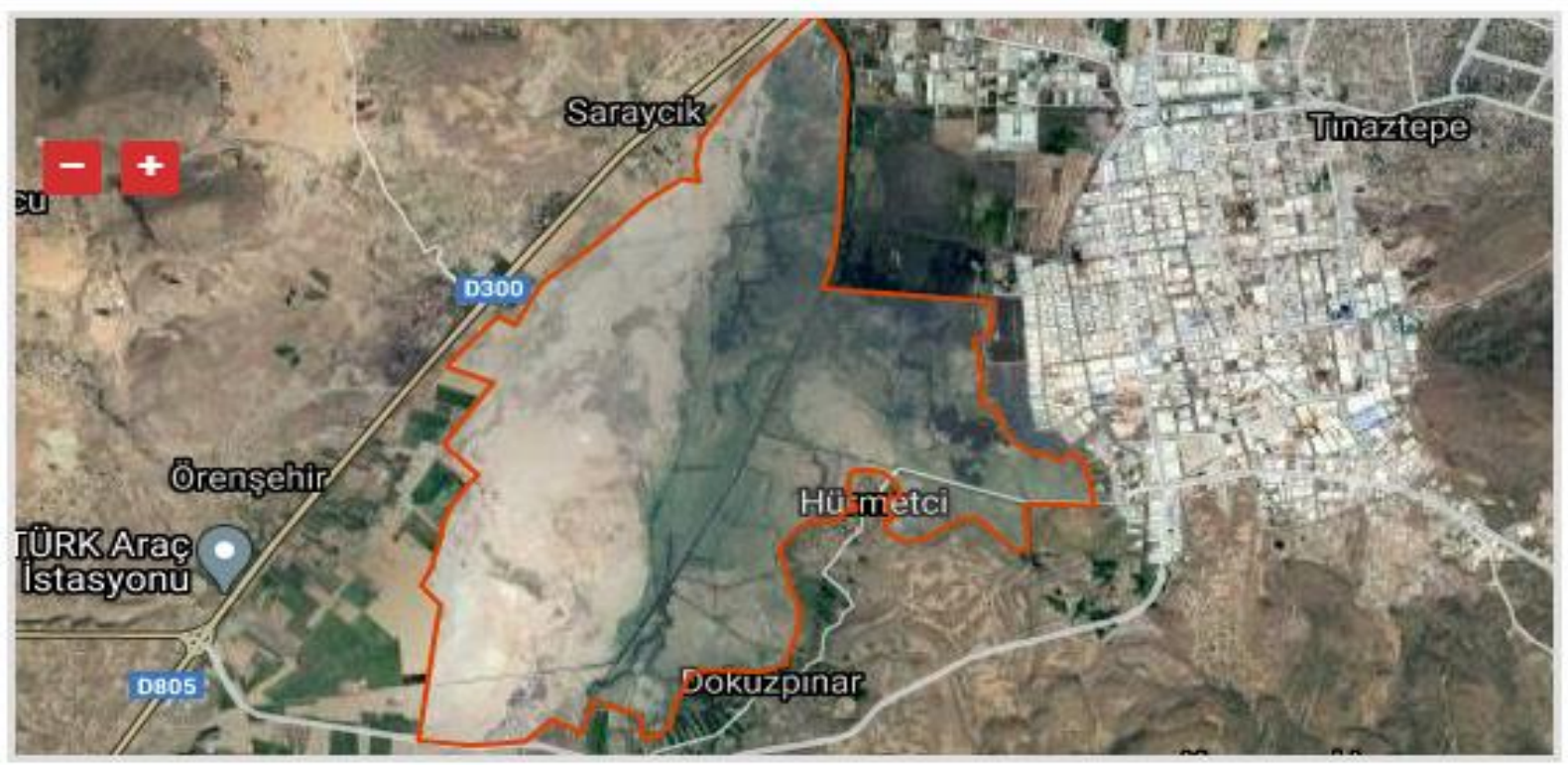

Şekil: 1. Hürmetçi Sazlığı'nın uydu görüntüsü (Tarım \& Orman Bakanlığı, 2021)

\subsection{Hürmetçi Sazlığının Ornito Faunası Potansiyeli}

Hürmetçi Sazlığı, 2004 yılında Ramsar kriterlerini taşımasından dolayı "Ulusal Öneme Haiz Sulak Alan” olarak tanımlanmıştır. Avrupa, Asya ve Afrika kuş göç yolu üzerinde bulunmasından dolayı da dünya ölçeğinde küresel öneme sahiptir. Ayrıca Kızılırmak havzasında olması ve Sultan Sazlığına yakınlığı itibariyle bu bölgelerde görülen kuş türlerinin Hürmetçi Sazlığında görülmesi muhtemeldir. 
Kuş gözlemcilerinin uzun süren takipleri ve şansları sayesinde daha farklı ve fazla kuş türünü gözlemlemeleri olasıdır.

BirdLife International tarafından “Avrupa Ölçeğinde Korumada Öncelikli Kuşlar” sınıflandırılmasına ve IUCN (International Union for Conservation of Nature) Red Data Book'a göre popülasyonu tehdit altında girmiş türler içinde olan "Toy(Ortis Tarda), Turna(Grus grus), Karaleylek(Ciconia nigra), Angıt(Tadorna ferruginea), Kaşıkçı(Platalea leucorodia), Bıyıklı Sumru(Chlidonias hybrida), Mahmuzlu Kızkuşu(Vanellus spinosus) ve Sürmeli Kızkuşu(Vanellus gregarius)" türlerinden bazıları bölgede göç döneminde görülmektedir. Bir kısmı da sazlıkta kuluçkaya yatmaktadır (Hacılar, 2021).

Hürmetçi sazlığının ornito faunasında Tarım ve Orman Bakanlığından elde verilere göre toplamda 136 adet kuş türü bulunmaktadır (Tarım \& Orman Bakanlığı, 2021). Listeye son dönemlerde rastlanmayan Toy (Ortis Tarda) alınmamıştır. Diğer nesli tehlike altında olan türler ve mevsimsel olarak ziyaretçi kuş türleri listede ayrıntılı olarak gösterilmiştir. Bu sayede ornito turizmi için bölgeyi ziyaret edecek olan kuş gözlemcilerinin planlamalarında bir yardımcı olabilecektir. Ek 1'de Hürmetçi Sazlığındaki kuşların listesi verilmiştir.

Afrika'nın kuzey bölgelerinden Türkiye'ye gelen leylekler, uzun yolculuklarında Hürmetçi Sazlığı'nda mola verdikleri gözlemlenmektedir. Avrupa, Asya ve Afrika kuş göç yolu üzerinde bulunan ve bünyesinde bulundurduğu geniş sulak alan ile de birçok kuş türünü barındıran Hürmetçi Sazlığı, kuzey Afrika'dan gelen birçok leyleğe de ev sahipliği yapmaktadır. Mart ayından itibaren binlerce kilometre uzaklıktan Hürmetçi Sazlığı'na gelen leylekler her yıl aynı yuvalara yerleştikleri gözlemlenmektedir. Leylekler, Hürmetçi Sazlığı'nın sulak alanında beslenerek, uzun yolculuklarında bir süre mola vermektedirler (Hacilar, 2021).

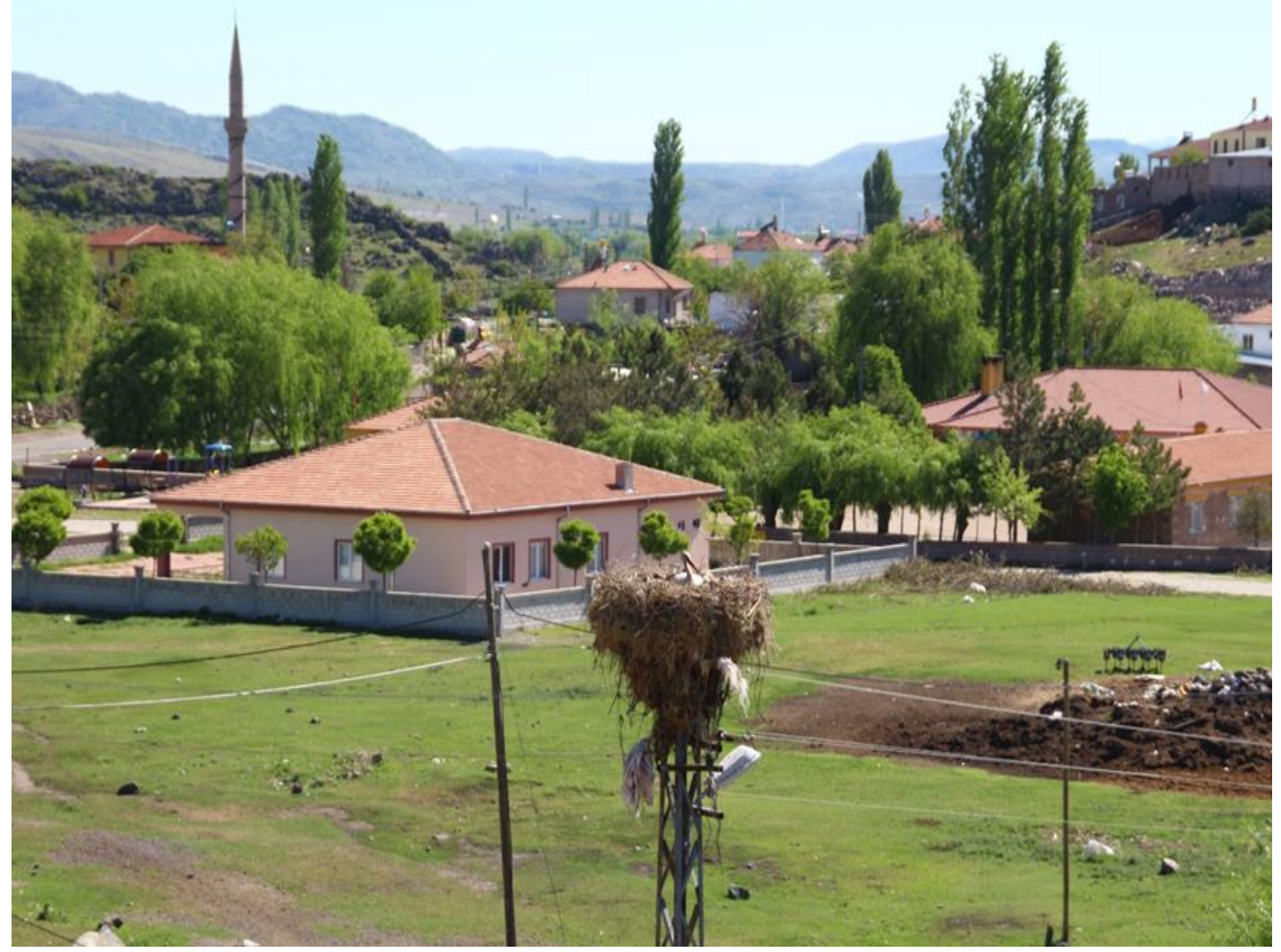

Fotoğraf 7. Hürmetçi Mahallesi leylek yuvası (Özer, 2021). 


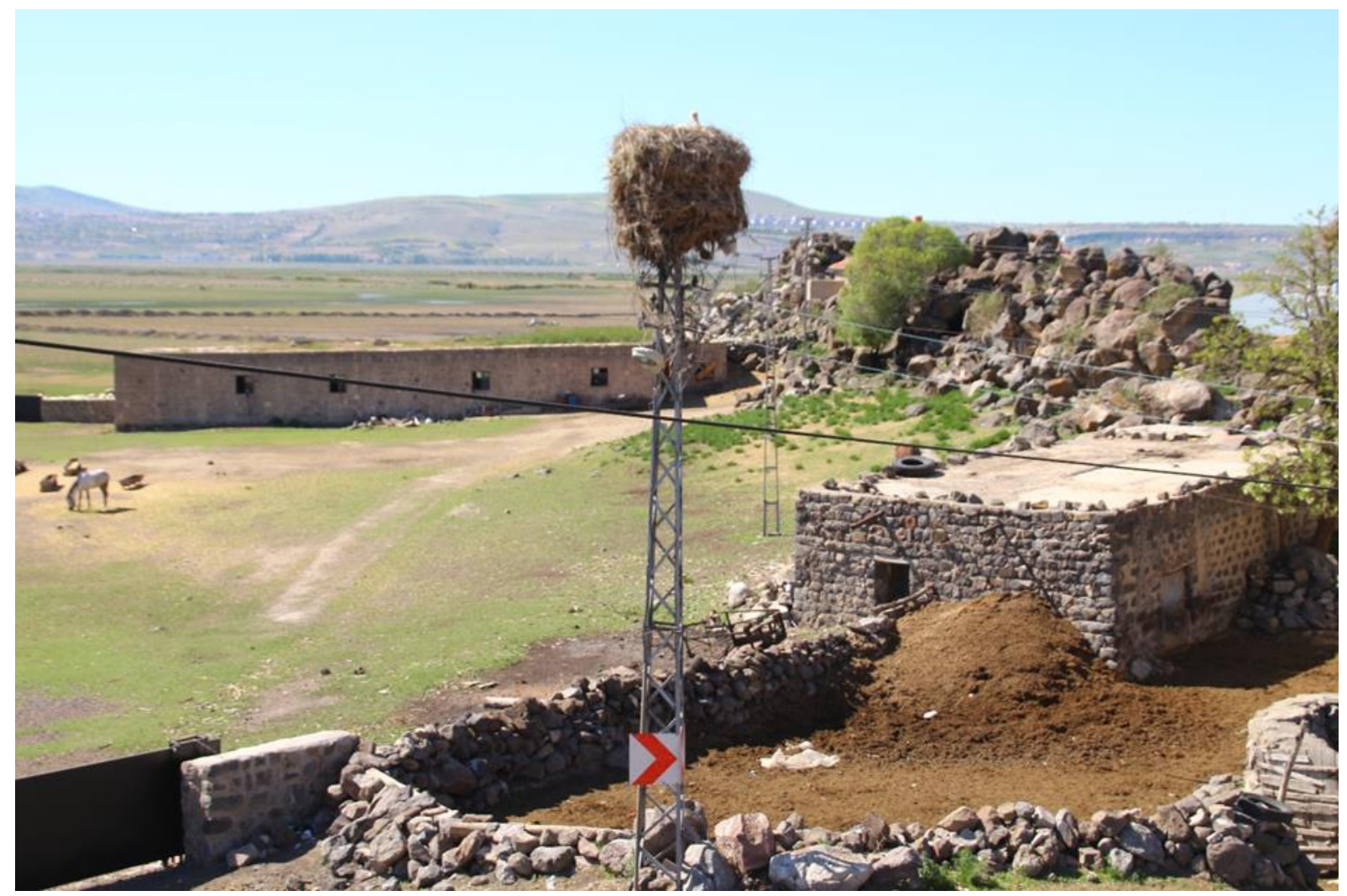

Fotoğraf 8. Hürmetçi Mahallesi leylek yuvası (Özer, 2021)

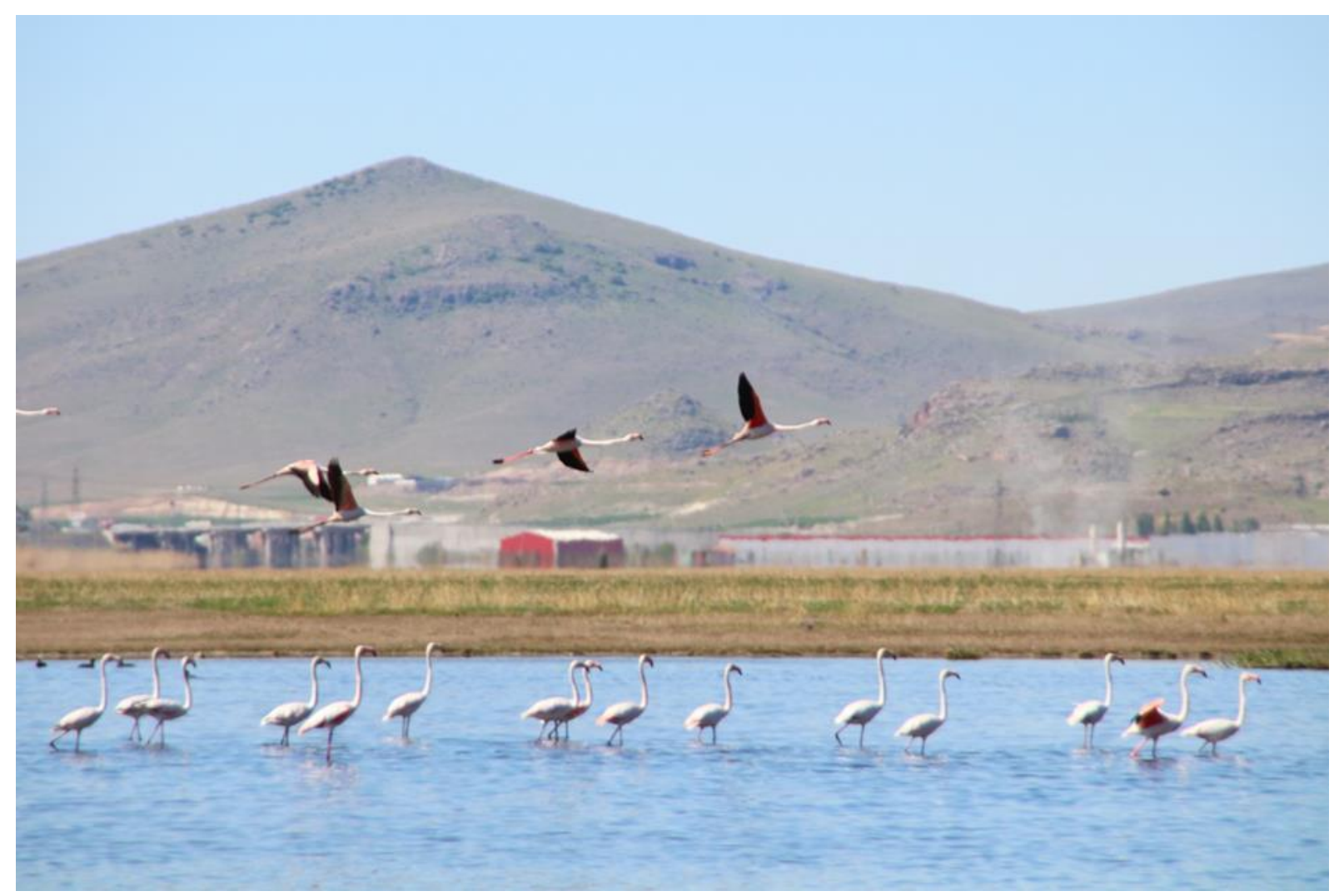

Fotoğraf 9. Hürmetçi Sazlığı filomingolar (Özer, 2021) 


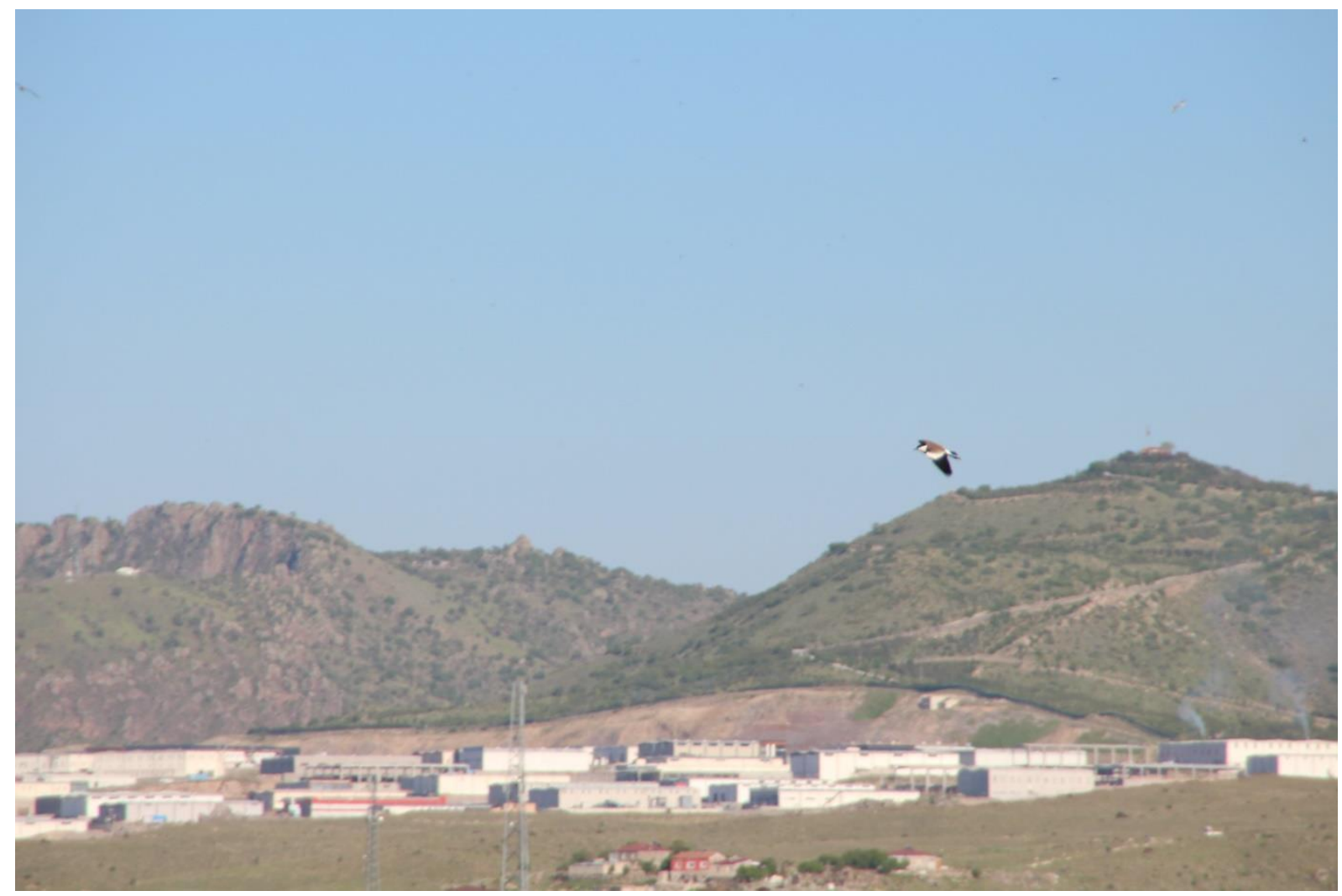

Fotoğraf 10. Hürmetçi Sazlığı Sürmeli Kızkuşu (Özer, 2021)

\subsection{Ornito Turizmi Açısından Hürmetçi Sazlığının Potansiyelinin Değerlendirilmesi}

Bu bölümde Hürmetçi Sazlığının ornito turizm açısından güçlü ve zayıf yönleri ile tehdit ve firsatları ortaya konulmuştur. Bölgeye ait zayıf yönleri güçlendirme, tehditleri ortadan kaldırma ve firsatları fark edip bunları avantaja dönüştürme şansı ise sonuçlar ve öneriler bölümüne konu edilmiştir.

\section{Hürmetçi Sazlığının Avantajları ve Güçlü Yönleri}

Hürmetçi Sazlığı konum itibariyle şehir merkezine yakın ve Kayseri’yi Ankara ve İstanbul'a yani Türkiye'nin batısına bağlayan D300 karayolunun hemen yanındadır. Böylelikle turizm olgularından ulaşımı için hiçbir sıkıntısı yoktur. Ulaşılabilirliğinin kolaylığı ortadadır.

Kapadokya'ya yarım saat kadar yakınlığı ayrıca bir avantaj sağlamaktadır. Bu avantaj iki türlüde değerlendirilebilmektedir. Birincisi Kapadokya'ya gelmiş olan bir turist Hürmetçi sazlığında kuş gözlemciliği yaparak bölgede kalış süresini bir gün daha uzatabilir. İkincisi ise Hürmetçi Sazlığına gelmiş bir kuş gözlemcisi Kültür turizmi veya Balon turizmi yapmak istediğinde Kapadokya’ya giderek bölgede kalış süresini uzatabilecektir. Kayseri merkeze ve Kapadokya'ya yakın olmasından dolayı, Kayserili ve Kapadokyalı kuş gözlemcileri tarafından günü birlik turizm kapsamında ziyaret edilebilmektedir.

Avrupa'nın ve Türkiye'nin birçok direk uçuşların olduğu Erkilet Havalimanına 15 kilometre yakınlıkta olması da ayrıca bir turizm potansiyeli oluşturmaktadır. Böylelikle Avrupa'dan gelecek olan kuş gözlemcileri için kolaylık ve çekicilik sağlamış olmaktadır. Bu durum Türkiye'nin uzak şehirlerinden gelen turistler içinde aynı şekilde önemli bir avantajdır. Özellikle göç mevsimindeki kuşları gözlemlemek adına hızlı hareket etmek gerekebilmektedir. Bu sayede kuş gözlemcileri planlarını kuşların hareket durumuna göre yapabileceklerdir. 
Erciyes Dağının eteklerinde olması bölgeye gelen kuş gözlemcilerini kalma süresi olarak farklı alternatif suna başka bir güçlü yöndür. Kış aylarında gelmiş olan kuş gözlemcileri aynı zamanda planlarına kayak turizmini de ekleyebilmektedirler. İki turizmin bir arada potansiyelinin kullanılması bakımından, kayak turizmi ile beraber kış ortası sukuşu sayımları yani KOSKS' a göre sazlıkta gözlenen kuş türlerini incelediğimizde; Sakarmeke(Fulica atra), Saz Tavuğu(Gallinula chloropus), Büyük Akbalıkç1(Egretta alba), Gri Balıkçıl(Ardea cinerea), Küçük Kuğu(Cygnus colombianus), Ötücü Kuğu(Cygnus cygnus), Angıt(Tadorna ferruginea), Suna(Tadorna tadorna), Kıl Kuyruk(Anas acuta), Yeşilbaş(Anas platyrhyrinchos), örnek olarak verilebilir (Doğa Derneği, 2013; Y1lmaz, 2018: 21).

Sultan Sazlığına ve Kızılırmak nehrine yakınlığından dolayı bölgeyi daha fazla transit kuşun ziyaret edebilme ihtimali vardır. Buda kuş gözlemcileri için bölgeyi ziyaretlerinde önemli bir etkendir. Ayrıca uzun süreli turizm faaliyetlerinde Sultan Sazlığında da kuş gözleminde bulunma avantajını da barındırmaktadır.

Zengin tarih, kültür ve tabiat varlıklarına yakın olması, kuş gözlemcilerinin Kayseri Kalesi, Türbeler vb. kültür turizmi aktivitelerini ve Yılkı atlarını fotoğraflanması ve at biniciliği gibi aktiviteleri programlarına dahil etmesine olanak sağlamaktadır.

Bölgedeki yerleşim yerlerinin kırsal görünüme sahip olması, turizm faaliyetleri için güven tesis etmesi ve gastronomi turizmi bakımından Manda yoğurdu, tereyağı gibi yöresel yemeklere sahip olması, bölgenin seçiminde avantaj sağlamaktadır.

Yerel yönetimin turizmin gelişimi konusunda istekliliği Hürmetçi sazlığının en güçlü yanını oluşturmaktadır. Şöyle ki bölgeye gelen kuş gözlemcileri belediyenin sağladığı toplu taşıma araçlarıyla kolaylıkla, Hürmetçi, Karpuzsekisi, Dokuzpınar ve Gelbula mahallerine ulaşım sağlayabilmektedirler.

Yerel halkın misafirperverliği sayesinde ornito turizmi için gelmiş olan turistler kendilerini rahat ve sıcak bir ortamda bulabilmektedirler. Yardım severlikleri ve turistlere olan pozitif ilgileri bölgeye gelen turistler tarafından takdir görmektedir. Bu özelliği ile sürdürebilir bir turizm döngüsüne sahip olabilmektedirler.

$\mathrm{Bu}$ avantajlara ilave olarak yaban hayatı bakımından; çakal, tilki, porsuk, gelengi, gelincik, yaban domuzu, yaban tavşanı ve yılkı atı gibi kürklü hayvanların alanda barınması ve üremesi sazlığın önemini bir derece daha artırmaktadır. Sazlığın yaban hayatı özellikleri nedeniyle her yıl birçok yerli ve yabancı bilim adamı, zoolog, doğasever, kelebek ve botanik gözlemcisi Hürmetçi Sazlığını ziyarette bulunmaktadir.

\section{Hürmetçi Sazlığının Dezavantajları- Zayıf Yönleri}

Öncelikle bölgede turizm alt yapısının eksikliği, ilk göz önüne gelen dezavantajıdır. Bunula beraber yerel halkın misafirperverliğinin iyi olmasının yanında turizm bilincinin zayıf olması ve tanıtım eksikliğinin olması bölgenin pazarlanması açısından önemli bir zayıflık olarak ortaya çıkmaktadır.

Hürmetçi sazlığının Sultan Sazlığı kadar turistik tanınırlığının etkin olmayışı ve alan hakkında bilgili alan kılavuzu, eğitimli turist rehberi ve kuş gözlem rehberinin eksikliği bölgenin ornito turizm açısından elini zayıflatmaktadır.

Kültürel ve doğal dokuya gerekli özenin gösterilmemesi ve bölge gezinde incelediğimiz tarihi yapılarda yeterli restorasyon yapılamaması dikkat çekici eksikliklerinden birisidir. 
Özel sektör ve kamu birimleri arasındaki bağlantının yeterince iyi yapılamaması ile sosyal hayatın canlı olmaması, sosyal aktivitelerin, konaklama tesislerinin eksikliği, kamu ve özel sektörün turizm ile ilgili çalışmalarının yeterince olmayışı, koordinasyon yönünden büyük eksikliktir. Bundan dolayı sazlığa ait pazarlama, olumlu imaj oluşturma ve markalaşma çalışmalarındaki eksiklikleri bölgenin yeterince bilinmemesine neden olmaktadır.

\section{Hürmetçi Sazlığının Fırsatları- Olanakları}

Günümüzde kitle turizmine olan ilginin azalması ve alternatif turizm türlerine olan ilginin artması buna bağlı olarak alternatif turizmlerin yapılabileceği Erciyes Dağı ve Tekir Yaylası'na olan yakın olması ve sahip olduğu çekicilikler ve doğal özellikler sebebiyle merak uyandırıyor olması yeni fırsatlar oluşturmaktadır.

Bölgede yaşayan yerel halkın turizme olan ilgisinin ve bilincinin gün geçtikçe artmaya başlaması ve Erciyes Master Planının uygulanmaya başlaması yeni olanakları ortaya çıkarmıştır (Güllü, 2018: 867).

Merkezi ve yerel yönetimlerin turizme verdiği önemi artırması ve entegre bir turizm için turizm bölgelerine yakınlığı, örneğin Kapadokya bölgesine yakınlığı ile ortak turizm projelerinin önünün açık olması şeklinde firsat oluşturabilmektedir.

Bölgeden göç ile yurt dışına gitmiş ve orada yaşamakta olan, iyi ilişkileri, tanıtım ve işbirliğinde yardım edebilecek insan potansiyelinin olması bölge tanıtımı için önemli bir olanaktır.

Bölgedeki yılkı atları ve manda üreticiliği bölgende yapılacak turizm çeşitlendirmesi için büyük bir firsat oluşturmaktadır. Gastronomi turizmi için manda sütünden ürünler ve macera turizmi için at biniciliği bölgede en önemli turizm gelir kaynağı olarak görülmektedir.

\section{Hürmetçi Sazlığında Tehditler - Tehlikeler}

Kitle turizm mantığının hâlâ devam ediyor olması, turizm sektöründeki işletmecilerin bölgedeki potansiyel turizmi yeterince algılayamamaları, teşvik ve yatırımda isteksiz olmaları sazlığa yakın turizm destinasyonlarının çekicilikleri Hürmetçi sazlığı için tehlike oluşturmaktadır.

Hürmetçi Sazlığı, Organize Sanayi’nin bölgeye doğru ilerleme isteğiyle tehdit altındadır. Sanayi faaliyetlerinin oluşturacağı çevresel kirliliğin artması, sazlığın çevresi, kuş faunası ve yaban hayatı üzerinde baskı oluşturmaktadır.

Sazlıktaki doğal kaynakların, koruma-kullanma dengesinden ve sürdürülebilirlikten uzak olarak kullanımlarının sürmesi, su kaynaklarının bilinçsiz kullanımı, sazlık alanların saz kesimi amacıyla tahrip ve yok edilmesi, otlatma amacıyla bazı turistik alanların kullanımı tarımsal faaliyetler için kullanımı, yerleşimin ve yapılaşmanın engellenememesi tehdit oluşturmaktadır. IUCN (International Union for Conservation of Nature) ve Turkish Bird Red Book kategorilerine göre tehdide açık türler içerisinde olan ve sazlığın biyoçeşitliliğinin iki önemli bölümü olan kuş türlerinin ve yaban hayatının sahip olduğu alanlar yok olma tehlikesi ile karşılaşmaktadır. Bunlarla beraber küresel ısınmanın neden olduğu iklim değişiklikleri de sazlığı tehdit altında bırakmakta, bölgenin özelliğini yitirme sürecine ivme katmaktadır (ÇED Raporu, 2009: 12).

\section{SONUÇ VE ÖNERILER}

Çalışmada elde edilen verilere göre Hürmetçi Sazlığının ornito turizmi yönünde pek çok avantaja ve güçlü yöne sahip olduğu görülmektedir. Konum olarak Kapadokya, Kayseri merkeze ve Erkilet Hava limanına olan yakınlığı, geçmişe uzanan tarihi ve kültürel yapısı, yerel haklın misafirperverliği, Asya, Afrika ve Avrupa kuş göç yolu üzerinde bulunması, Kızılırmak havzasında olması, ornito faunası yüksek 
olan Sultan Sazlığına yakınlığı ile kuş gözlemcilerinin farklı ve fazla kuş türünü gözlemlemesi, “Avrupa Ölçeğinde Korumada Öncelikli Kuşlar” kategorilendirilmesine ve IUCN Red Data Book’a göre popülasyonun tehdit altında girmiş türler içinde olan "Toy (Ortis Tarda), Angıt (Tadorna ferruginea), Turna (Grus grus), Kaşıkçı (Platalea leucorodia), Bıyıklı Sumru (Chlidonias hybrida), Karaleylek (Ciconia nigra), Mahmuzlu Kızkuşu (Vanellus spinosus) ve Sürmeli Kızkuşu (Vanellus gregarius)” türlerinden bazıları bölgede göç sezonunda görülmesi, bir kısmının da sazlıkta kuluçkaya yatması ve toplamda ornito faunasında 136 adet kuş türü bulunması (Tarım \& Orman Bakanlığı, 2021), Hürmetçi Sazlığını ornito turizmi açısından güçlü kılmaktadır.

Ancak bölgede doğal kaynakların, sürdürülebilirlikten uzak bir şekilde kullanılmasından dolayı, ciddi çevresel sorunlar yaşanmaktadır. Sultan Sazlığının kuruma tehlikesiyle karşı karşıya olması nedeniyle, yaban hayatı ve kuş gözlemciliği hayati öneme sahip Hürmetçi Sazlığının önemi daha da ortaya çıkmıştır. Hürmetçi Sazlığı IUCN kategorilerine göre, popülasyonu tehdit altında olan farklı kuş türlerinin sazlıkta göç sezonunda gözlemlenmesi ve kuluçkaya yatması ve yine birçok biyoçeşitliliğin bölgede barınması ve üremesinden dolayı yaban hayatı bakımından önemli bir sulak alandır (ÇED Raporu, 2009: 12).

Hürmetçi Sazlığı ve mevcut sulak alanların tümünün problemlerinin çözülmesinde "Sulak Alanların Korunması Yönetmeliği”'nin tam uygulanması gerekmektedir. Ayrıca karar verme yetkisine sahip olan siyasetçilerin, yöneticilerin ve planlayıcıların sulak alanların önemi hususundaki bilgilerini yükseltmek amaçlı çalışmalar yapılmalıdır. Örneğin; 'Sulak Alanlar ve Turizm Çalıştayı' yapılarak yerel halkın, sivil toplum örgütlerinin ve karar vericilerin katılımları sağlanmalıdır. Sulak alanların yönetim planlarının hazırlanması sürecinde, etkili denetim ve izleme sistemleri kurulmalıdır. Bunlarla beraber küresel ısınmanın neden olduğu iklim değişikliklerinin etkilerini en aza indirilebilmek amaçlı ülke genelinde ilgili bakanlıklar tarafından etkin ve uygulanabilir politikalar oluşturulmalıdır (ÇED Raporu, 2009: 13).

Hürmetçi Sazlığı Kayseri merkeze yakınlığıyla, içinde bulundurduğu değerlerle kolaylıkla Milli Park olarak nitelendirilebilecek potansiyele sahiptir. Elindeki potansiyeli ile turizm için önemli bir bölgedir. Unutulmaması gereken nokta ise turistik faaliyetlerin çevreye duyarlı uygulamaları bulundurmaması yaban hayatı bakımından kötü sonuçlar doğuracaktır. Yapılan plan ve projeler öncelikle çevreyi, doğayı ve tabiatı koruyacak şekilde olmalıdır. Örneğin; Türkiye'nin korunan alanlar listesindeki Milli Park veya Tabiat parkı olarak belirlenmesi, nitelendirilmesi ve statüsünün verilmesi, Hürmetçi Sazlığı'nın sürdürülebilirliği açısından önemlidir. Böylelikle sürdürülebilir turizm için kaynak oluşturacaktır. Hürmetçi Sazlığı yapılacak yeni projeler ve planlar için öncesinde yapılmış olan planların ve alınmış plan kararlarının, komşusu Sultan Sazlığı Milli Parkının plan ve kararları ile eşgüdümlülüğünün sağlanması gerekmektedir.

Hürmetçi Sazlığının karşındaki bir diğer tehlike olan yapılaşma-kentleşme baskısının önüne geçilmesi için bakanlık tarafından "Erciyes Turizm Gelişim Bölgesi”ni kapsayacak yapılması planlanan projeler veya programlarla ilişkilendirilmesi gerekmektedir. Bölgenin etrafındaki doğal yaşam alanları ile birlikte korunması amacıyla "Sulak Alan Yönetim Planlaması” yapılması gerekmektedir. Sazlığın sanayi ve yerleşim stresinden uzak tutulması gereklidir. Mevcut durum ve genişlemesi muhtemel Organize Sanayi Bölgesinde alan ve faaliyet tanımlamalarının oluşturulması gerekmektedir. Organize sanayinin ilerlemesi durdurulmalı, çevre ve doğaya verebileceği zararları engellemek için kontrollerin ve denetimlerin sıklaştırılması gereklidir.

Ayrıca bölgedeki mahallelerde turizm alt yapısının ve konaklama tesislerinin eksikliği en belirgin zayıflığıdır. Turizm hakkındaki bilgi eksikliği ve pazarlama araçlarının aktif ve güçlü kullanılmaması, 
turistik tanıtımının zayıf olması ve alan hakkında bilgili alan kılavuzu, eğitimli rehber ve kuş gözlem rehberinin eksikliği bölgenin ornito turizm açısından elini zayıflatmaktadır.

Özel sektör ve kamu birimleri arasındaki bağlantının yeterince iyi yapılmaması ile sosyal hayatın canlı olmaması, sosyal aktivitelerin, konaklama tesislerinin eksikliği, kamu ve özel sektörün turizm ile ilgili çalışmalarının yeterince olmayışı, koordinasyon yönünden büyük eksikliktir. Bundan dolayı sazlığa ait pazarlama, olumlu imaj oluşturma ve markalaşma çalışmalarına önem gösterilmesi, sazlığın ornito turizm açısından yüksek oranda gelirlerini artırabilecektir.

Bununla birlikte ornito turizminin geliştirilmesinde, ön plana çıkarılmasında bölgenin sahip olduğu ve kullanılması gereken farklı firsatlar bulunmaktadır. Bu firsatlar; eko turizm türlerine olan ilginin artması, bölgede yaşayan yerel halkın turizme olan ilgisinin bilincinin günden güne artması, sahip olduğu çekicilikler ve ornito faunası sebebiyle merak uyandırması şeklinde sıralanabilir. Erciyes Master Planının uygulanmaya başlaması üzerinde daha çok çalışılması ve kullanılmasının gerektiğini göstermektedir. Merkezi ve yerel yönetimlerin turizme verdiği önemi artışı ve entegre bir turizm için turizm bölgelerine yakınlığı, örneğin Kapadokya’ya yakınlığg ile ortak turizm projelerinin önünün açık olması şeklinde firsat oluşturabilmektedir. Kapadokya'daki balon turizmine Hürmetçi kuş gözlemciliği turizmi entegre edilebilir. Bölgeden göç ile yurt dışına gitmiş ve orada yaşamakta olan, iyi ilişkileri, tanıtım ve işbirliğinde yardım edebilecek insan potansiyeli bölge tanıtımı için önemli bir olanaktır.

Bölgedeki yılkı atları ve manda üreticiliği bölgede yapılacak turizm çeşitlendirmesi için büyük bir fırsat oluşturmaktadır. Gastronomi turizmi için manda sütünden ürünler macera turizmi için at biniciliği bölgede en önemli turizm gelir kaynağı olarak görülmektedir. Bu doğal kaynakların değerlendirilmesi ile eko turizminin alt dalı olan ornito turizmi için çok elverişli bir bölgedir. Çalışma bölgeye gelecek olan kuş gözlemcileri için bir rehber olabilecektir.

Hürmetçi Sazlığındaki alternatif turizm türleri ile bölgeyi maddi ve manevi açışından iyi refah seviyesine ve daha ileri konuma taşıyabileceği düşünülmektedir. Bölgeye yapılması gerekenlerin başında doğaya uyumlu bir gözlem kulesi yapılmalıdır. Sonrasında yerel halka eğitimler verilerek istekli olanlarında kuş gözlem rehberi yapılması bölgeye ekonomik ve sosyal fayda sağlayacaktır. Rehberlik eğitimin daha profesyonelce yapılması amacıyla turist rehberliği uzmanlık alanlarına ornito turizm rehberliği eklenmesi, Erciyes Üniversitesi Turizm Fakültesi Turizm Rehberliği Bölümünde buna yönelik derslerin eklenmesi, bu konuda turist rehberlerinin yetiştirilmesi açısından daha doğru olduğu düşünülmektedir. Bölgedeki konaklama eksikliğini de ev pansiyonculuğu yöntemiyle çözmek yerel halkın ekonomik gelir seviyesini artırmak için önemli bir yöntem olduğu düşünülmektedir.

Hürmetçi Sazlığında kuş gözlemciliği turizminin geliştirilmesi için bölgenin sahip olduğu güçlü yönleri iyi kullanmak, zayıf yönleri güçlendirmek, firsatları iyi değerlendirmek ve tehdit oluşturabilecek durumları ise minimum düzeye indirmek gereklidir.

Uzmanlık alanı özel ilgi turizmi olan araştırmacılarının özellikle Avrupa tabanlı kaynakları incelemeleri doğru bilgiye hızlı bir şekilde ulaşmaları için önemlidir. Kuş gözlemciliği ve doğa ile ilgili güncel olayları takip etmek için doğa derneğinin web sayfasını takip etmeleri faydalı olacaktır. Böylelikle hem kuş gözlemciliği faaliyetlerine hem de çalışmaları için verilere ulaşmaları açısından kullanışlı olacaktır. Çalışmanın bundan sonraki Kayseri, Hürmetçi Sazlığı ve ornito turizmi ile ilgili çalışmalara destek olacağı düşünülmektedir. 


\section{KAYNAKÇA}

Akmeşe, H. \& Ilgaz, A. (2019). Develi ilçesinin ornito turizm potansiyelinin değerlendirilmesi İçinde: Talas, M. \& Söylemez, A. (Eds), 2. Uluslararası Erciyes Bilimsel Araştırmalar Kongresi, (178-183). Kayseri.

Arslan Gündoğdu, Z. (2005). İstanbul-Belgrad Ormanı'nın ornito faunası üzerinde araştırmalar, Yayınlanmamış Doktora Tezi, İstanbul Üniversitesi Fen Bilimleri Enstitüsü, İstanbul.

Asan, H., Yalçın, H.M. \& Şimşek, E. (2018). Sivas ili kuş gözlem turizmi potansiyelinin değerlendirilmesi. Akademik Sosyal Araştırmalar Dergisi, 6(74), 630-655.

Aslan, A. (2019). Kuş gözlemcileri ve fotoğrafçılarının profili, Yayınlanmamış Yüksek Lisans Tezi. İstanbul Üniversitesi-Cerrahpaşa Lisansüstü Eğitim Enstitüsü Orman Mühendisliği Anabilim Dalı Orman Mühendisliği Programı, İstanbul.

Bahçe, S. (Ed.) (2013). Alternatif turizm. Eskişehir. T.C. Anadolu Üniversitesi Yayını No: 2744

Ceballos-Lascuráin, H. (1996). Tourism, ecotourism and protected areas. Gland, Switzerland: IUCN Publication Services Unit.

Cordell, H.K. \& Herbert, N.G. (2002). The popularity of birding is still growing. Birding, (34), 54-59.

Çakıcı, C. \& Harman, S. (2006). Kuş gözlemciliğinin önemi: Türkiye'de kuş gözlemcilerinin profili, Anatolia: Turizm Araştırmaları Dergisi, 17(2), 161-168.

ÇED Raporu (2009). Türkiye'nin stratejik çevresel değerlendirme uygulama kapasitesinin güçlendirilmesi projesi, Kayseri.

Çorba, C. (2019). Alternatif bir ekoturizm faaliyeti olarak kuş gözlem turizmi açısından Muğla ili incelemesi, Yayınlanmamış Yüksek Lisans Tezi İzmir Kâtip Çelebi Üniversitesi Fen Bilimleri Enstitüsü, İzmir.

Doğa Derneği, (2013). Hürmetçi Sazlığı kış ortası sukuşu sayımları verisi (KOSKS). https://www.dogadernegi.org/kis-ortasi-sukusu-sayimlari/, Erişim Tarihi: 15.04.2020.

Erdoğan, A. Deval, C. Öz, M. Ünal, O. Yavuz, Gökoğlan, M. Özvarol, A. Gülyavuz, H., Karaardıç, H. \& Kaçar, M. S. (2010). Titreyen Göl ve çevresinin flora-faunasının tespiti ile Titreyen Göl su kalitesinin belirlenmesi raporu. Akdeniz Üniversitesi Manavgat Meslek Yüksek Okulu, Antalya.

Gülbahar, O. (2009). 1990'lardan günümüze Türkiye'de kitle turizminin gelişimi ve alternatif yönelimler. Süleyman Demirel Üniversitesi İktisadi ve İdari Bilimler Fakültesi Dergisi.14(1),151177.

Güllü, K. (2018). Bir turizm destinasyonu olarak Develi'nin turizm potansiyelini belirlemeye yönelik bir swot analizi, BMIJ, 6(4), 862-877. doi: http://dx.doi.org/10.15295/bmij.v6i4.402.

Gürlük, S. \& Rehber, E. (2008). A travel cost study to estimate recreational value for a bird refuge at Lake Manyas Turkey. Journal of Environmental Management, 88(4), 1350-1360.

Hacılar (2021). Hürmetçi Sazlığı, from http://www.hacilar.gov.tr/hurmertci-sazligi-sulak-alani, Erişim Tarihi: 08.04.2021

Kandır, H. \& Erturhan, Z. (2015). Doğadaki görsel şölen: Kuşlar ve kuş gözlemciliği, Göller Bölgesi Aylık Hakemli Ekonomi ve Kültür Dergisi Ayrıntı,15-20.

Kiziroğlu, İ. (2008). Türkiye kuşları kırmızı listesi. Ankara: Desen Matbaası.

Kuştr (2021). from http://kustr.org/kusatlasi/, Erişim Tarihi: 15.04.2021.

Kültür \& Turizm Bakanlığı (2021). https://kayseri.ktb.gov.tr/TR-183224/hurmetci-sazligi.html, Erişim Tarihi: 20.04.2021.

Özer, O. (2021). Hürmetçi Sazlığı ve kuş gözlem fotoğrafları. Canon 650D. 
Özkazanç, N., \& Özay, E., (2019). The factors that threaten the migratory birds. Bartın University International Journal of Natural and Applied Sciences, 2(1), 77-89.

Pekçetinöz, B. (2006). Denizel koruma alanlarında ekoturizmin bir segmenti olarak kuş gözlemciliği aktiviteleri ve İzmir Kuş Cennetinin potansiyeli. Yayınlanmamış Yüksek Lisans Tezi, Dokuz Eylül Üniversitesi, Deniz Bilimleri ve Teknolojisi Enstitüsü Kıyı Bölgesi Yönetimi Programı, İzmir.

Pekin, F. (2011). Çözüm: Kültür turizmi. İstanbul: İletişim Yayınları.

Responsible Travel (2021). https://www.responsibletravel.org/impact-tourism-handbook/lapa-riosecolodge-and-reserve-a-pioneers-story/, Erişim Tarihi: 14.04.2021.

Şekercioğlu, Ç.H. (2002). Impacts of birdwatching on human and avian communities. Environmental Conservation, 29, 282-289.

Sert, A. N. \& Arslan, M. (2019). Türkiye'deki kuş gözlemcilerinin motivasyon ve destinasyon tercihlerinin belirlenmesi, Manas Sosyal Araştırmalar Dergisi, 8(2), 2104-2124.

Sevindi, C. (2013). Ekoturizm ve kuş gözlemciliği açısından Kuyucuk Gölü Kuş Cenneti (ArpaçayKars). Türk Coğrafya Dergisi, 61, 63-76.

Sezgin, M. \& Ünüvar Ş. (2008). Kültürler arası iletişimde turizmin önemi, alternatif turizm ve pazar olgusu. Journal of Azerbaijani Studies, 11(2), 392-404.

Sop, S.A. (2015). Kuş gözlemciliği ve turizm ilişkisi: burdur gölü üzerine bir tartışma İçinde: Kazan Nas, Ş. (Ed), I. Teke Yöresi Sempozyumu, Burdur, 543-549.

Tarım \& Orman Bakanlığı (2021). https://saybis.tarimorman.gov.tr/Home/Detay, Erişim tarihi 21. 04. 2021.

Topay, M. \& Parladır M. Ö. (2015). Isparta ili örneğinde CBS yardımıyla alternatif turizm etkinlikleri için uygunluk analizi. Tarım Bilimleri Dergisi, 21(2), 300-309.

Trauer, B. (2006). Conceptualizing special interest tourism frameworks for analysis. Tourism Management, 27(2), 183-200.

Tunç, F. (2018). Manavgat ilçesinin ornitoturizm potansiyeli. Yayınlanmamış Yüksek Lisans Tezi, Akdeniz Üniversitesi Sosyal Bilimler Enstitüsü Coğrafya Ana Bilim Dalı, Antalya.

Yılmaz, Ş. (2018). Hürmetçi Sazlığı (Kayseri) koruma alanının ağır metal kirliliği açısından değerlendirilmesi, Yayınlanmamış Yüksek Lisans Tezi, Erciyes Üniversitesi Fen Bilimleri Enstitüsü Biyoloji Anabilim Dalı, Kayseri. 
EK 1:

Tablo 1. Hürmetçi Sazlığının Kuş Faunası (Tarım \& Orman Bakanlığı, 2021)

\begin{tabular}{|c|c|c|c|c|}
\hline Bilimsel Ad & Türkçe Ad & iUCN Kategorileri & $\begin{array}{l}\text { Endemizm } \\
\text { Durumu }\end{array}$ & Göç Durumu \\
\hline Calidris alba & Ak kumkuşu & $\begin{array}{l}\text { LC- Least Concern } \\
\text { (En Az Endişe } \\
\text { Verici) }\end{array}$ & Endemik Değil & Transit göçmen \\
\hline Motacilla alba & Ak kuyruksallayan & // & $/ /$ & Yerli \\
\hline Charadrius alexandrinus & Akça cilibit & // & $/ /$ & Yerli \\
\hline Falco vespertinus & Ala doğan & $\begin{array}{l}\text { NT-Near Threatened } \\
\text { (Tehdit Altına } \\
\text { Girebilir) }\end{array}$ & $/ /$ & Transit göçmen \\
\hline Ardeola ralloides & Alaca balıkçıl & $\begin{array}{l}\text { LC- Least Concern } \\
\text { (En Az Endişe } \\
\text { Verici) }\end{array}$ & $/ /$ & Yaz ziyaretçisi \\
\hline Strix aluco & Alaca baykuş & // & $/ /$ & Yerli \\
\hline Garrulus glandarius & Alakarga & // & $/ /$ & Yerli \\
\hline Tadorna ferruginea & Angit & // & // & Yerli \\
\hline Merops apiaster & Arıkuşu & // & $/ /$ & Yaz ziyaretçisi \\
\hline Accipiter nisus & Atmaca & $/ /$ & $/ /$ & Yerli \\
\hline Podiceps cristatus & Bahri & // & $/ /$ & Yerli \\
\hline Locustella luscinioides & Bataklık kamışçını & // & $/ /$ & Transit göçmen \\
\hline Muscicapa striata & Benekli sinekkapan & // & $/ /$ & Yaz ziyaretçisi \\
\hline Coturnix coturnix & Bildırcin & // & $/ /$ & Yaz ziyaretçisi \\
\hline $\begin{array}{l}\text { Acrocephalus } \\
\text { melanopogon }\end{array}$ & Bıyıklı kamışçın & $/ /$ & $/ /$ & Yaz ziyaretçisi \\
\hline Chlidonias hybrida & B1y1kl1 sumru & // & $/ /$ & Yaz ziyaretçisi \\
\hline Melanocorypha calandra & Boğmaklı toygar & $/ /$ & $/ /$ & Yerli \\
\hline Oenanthe isabellina & Boz kuyrukkakan & // & $/ /$ & Yaz ziyaretçisi \\
\hline $\begin{array}{l}\text { Calandrella } \\
\text { brachydactyla }\end{array}$ & Bozkır toygarı & $/ /$ & $/ /$ & Transit göçmen \\
\hline Luscinia megarhynchos & Bülbül & // & $/ /$ & Yaz ziyaretçisi \\
\hline Ardea alba & Büyük ak balıkçıl & // & $/ /$ & Yaz ziyaretçisi \\
\hline Parus major & Büyük baştankara & // & $/ /$ & Yerli \\
\hline $\begin{array}{l}\text { Acrocephalus } \\
\text { arundinaceus }\end{array}$ & Büyük kamışçın & $/ /$ & $/ /$ & Yaz ziyaretçisi \\
\hline Accipiter gentilis & Çakırkuşu & // & $/ /$ & Yerli \\
\hline Acrocephalus palustris & Çalı kamışçını & $/ /$ & $/ /$ & Transit göçmen \\
\hline Anas crecca & Çamurcun & // & // & Kış ziyaretçisi \\
\hline Limosa limosa & Çamurçulluğu & $\begin{array}{l}\text { NT-Near Threatened } \\
\text { (Tehdit Altına } \\
\text { Girebilir) }\end{array}$ & $/ /$ & Transit göçmen \\
\hline Saxicola rubetra & Çayır taşkuşu & $\begin{array}{l}\text { LC- Least Concern } \\
\text { (En Az Endişe } \\
\text { Verici) }\end{array}$ & $/ /$ & Yaz ziyaretçisi \\
\hline Plegadis falcinellus & Çeltikçi & // & $/ /$ & Yaz ziyaretçisi \\
\hline Anas querquedula & Çıkrıkçın & // & $/ /$ & Yaz ziyaretçisi \\
\hline Phylloscopus collybita & Çıvgın & // & $/ /$ & Yaz ziyaretçisi \\
\hline Falco subbuteo & Delice doğan & // & // & Yaz ziyaretçisi \\
\hline Philomachus pugnax & Döğüşkenkuş & $/ /$ & $/ /$ & Transit göçmen \\
\hline Apus apus & Ebabil & // & // & Yaz ziyaretçisi \\
\hline Aythya ferina & Elmabaş patka & // & $/ /$ & Yerli \\
\hline Ardea purpurea & Erguvani balıkçıl & // & // & Yaz ziyaretçisi \\
\hline Delichon urbicum & Ev kırlang1c1 & // & // & Yaz ziyaretçisi \\
\hline Phoenicopterus roseus & Flamingo & // & $/ /$ & Yaz ziyaretçisi \\
\hline Circus cyaneus & Gökçe delice & // & $/ /$ & Kış ziyaretçisi \\
\hline Coracias garrulus & Gökkuzgun & $\begin{array}{l}\text { NT-Near Threatened } \\
\text { (Tehdit Altına } \\
\text { Girebilir) }\end{array}$ & $/ /$ & Yaz ziyaretçisi \\
\hline
\end{tabular}


Özer (2021), Johti, 3(1), 37-54

\begin{tabular}{|c|c|c|c|c|}
\hline Ardea cinerea & Gri balıkçıl & $\begin{array}{l}\text { LC- Least Concern } \\
\text { (En Az Endişe } \\
\text { Verici) }\end{array}$ & // & Yaz ziyaretçisi \\
\hline Pluvialis squatarola & Gümüș yağmurcun & $/ /$ & // & Kış ziyaretçisi \\
\hline Charadrius hiaticula & Halkalı c1libit & // & /I & Transit göçmen \\
\hline Charadrius dubius & Halkalı küçük cılıbıt & // & // & Yaz ziyaretçisi \\
\hline Larus cachinnans & Hazar martıs1 & // & // & Kış ziyaretçisi \\
\hline Upupa epops & İbibik & $/ 1$ & // & Yaz ziyaretçisi \\
\hline Fringilla coelebs & İspinoz & // & // & Yerli \\
\hline Phoenicurus ochruros & Kara kızılkuyruk & // & // & Yaz ziyaretçisi \\
\hline Ciconia nigra & Kara leylek & // & // & Transit göçmen \\
\hline Phalacrocorax carbo & Karabatak & // & // & Kış ziyaretçisi \\
\hline Oenanthe hispanica & $\begin{array}{l}\text { Karakulaklı } \\
\text { kuyrukkakan }\end{array}$ & // & $/ /$ & Yaz ziyaretçisi \\
\hline Turdus merula & Karatavuk & // & // & Yerli \\
\hline Platalea leucorodia & Kaşıkçı & /I & // & Yaz ziyaretçisi \\
\hline Anas clypeata & Kaşıkgaga & $/ 1$ & // & Kış ziyaretçisi \\
\hline Emberiza cia & Kaya çintesi & $/ /$ & // & Yerli \\
\hline Columba livia & Kaya güvercini & // & // & Yerli \\
\hline Falco tinnunculus & Kerkenez & $/ /$ & // & Yerli \\
\hline Recurvirostra avosetta & Kılıçgaga & // & // & Yerli \\
\hline Anas acuta & Kılkuyruk & /I & /I & Yaz ziyaretçisi \\
\hline Alectoris chukar & Kınalı keklik & // & // & Yerli \\
\hline Anthus campestris & Kır incirkuşu & // & // & Yaz ziyaretçisi \\
\hline Hirundo rustica & Kır kırlangıcı & // & // & Yaz ziyaretçisi \\
\hline Calidris ferruginea & Kızıl kumkuşu & // & // & Transit göçmen \\
\hline Buteo rufinus & Kızıl şahin & /I & // & Yerli \\
\hline Tringa totanus & Kızılbacak & $1 /$ & // & Kış ziyaretçisi \\
\hline Lanius senator & $\begin{array}{l}\text { Kizılbaşlı } \\
\text { örümcekkuşu }\end{array}$ & // & // & Yaz ziyaretçisi \\
\hline Erithacus rubecula & Kızılgerdan & // & // & Kış ziyaretçisi \\
\hline Lanius collurio & $\begin{array}{l}\text { Kizılsırtli } \\
\text { örümcekkuşu }\end{array}$ & // & // & Yaz ziyaretçisi \\
\hline Vanellus vanellus & Kızkuşu & // & // & Yerli \\
\hline Emberiza hortulana & Kirazkuşu & // & // & Yaz ziyaretçisi \\
\hline Burhinus oedicnemus & Kocagöz & // & // & Yaz ziyaretçisi \\
\hline Athene noctua & Kukumav & // & // & Yerli \\
\hline Streptopelia decaocto & Kumru & /I & /I & Yerli \\
\hline Oenanthe oenanthe & Kuyrukkakan & // & // & Yaz ziyaretçisi \\
\hline Corvus corax & Kuzgun & // & // & Yerli \\
\hline Egretta garzetta & Küçük akbalıkçıl & // & /I & Yaz ziyaretçisi \\
\hline Ixobrychus minutus & Küçük balaban & // & // & Yaz ziyaretçisi \\
\hline Tachybaptus ruficollis & Küçük batağan & // & // & Yerli \\
\hline Serinus serinus & Küçük iskete & /I & /I & Yerli \\
\hline Cygnus columbianus & Küçük kuğu & // & // & Kış ziyaretçisi \\
\hline Calidris minuta & Küçük kumkuşu & // & /I & Kış ziyaretçisi \\
\hline Ciconia ciconia & Leylek & $/ /$ & $/ /$ & Yaz ziyaretçisi \\
\hline Netta rufina & Macar ördeği & // & // & Kış ziyaretçisi \\
\hline Vanellus spinosus & Mahmuzlu kızkuşu & // & // & Yaz ziyaretçisi \\
\hline Lanius nubicus & $\begin{array}{l}\text { Maskeli } \\
\text { örümcekkuşu }\end{array}$ & // & // & Yaz ziyaretçisi \\
\hline Cyanistes caeruleus & Mavi baştankara & $/ /$ & // & Yerli \\
\hline Lullula arborea & Orman toygarı & /I & // & Yerli \\
\hline Turdus philomelos & Öter ardıç & /1 & // & Yerli \\
\hline Cygnus cygnus & Ötücü kuğu & /I & // & Kış ziyaretçisi \\
\hline Aythya nyroca & Pasbaş patka & $\begin{array}{l}\text { NT-Near Threatened } \\
\text { (Tehdit Altına } \\
\text { Girebilir) }\end{array}$ & // & Yaz ziyaretçisi \\
\hline Carduelis carduelis & Saka & $\begin{array}{l}\text { LC- Least Concern } \\
\text { (En Az Endişe } \\
\text { Verici) }\end{array}$ & // & Yerli \\
\hline
\end{tabular}




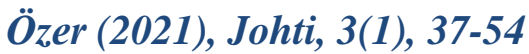

\begin{tabular}{|c|c|c|c|c|}
\hline Fulica atra & Sakarmeke & // & // & Yerli \\
\hline Pica pica & Saksağan & // & // & Yerli \\
\hline Motacilla flava & Sarı kuyruksallayan & // & // & Yaz ziyaretçisi \\
\hline Circus aeruginosus & Saz delicesi & // & // & Yerli \\
\hline Acrocephalus scirpaceus & Saz kamışçını & $/ /$ & $/ /$ & Transit göçmen \\
\hline Passer domesticus & Serçe & // & // & Yerli \\
\hline Sturnus vulgaris & Sığırcık & // & // & Yerli \\
\hline Passer hispaniolensis & Söğüt serçesi & // & // & Yerli \\
\hline Phylloscopus trochilus & Söğütbülbülü & // & // & Transit göçmen \\
\hline Gallinago gallinago & Suçulluğu & // & // & Transit göçmen \\
\hline Rallus aquaticus & Sukılavuzu & // & // & Yerli \\
\hline Tadorna tadorna & Suna & // & // & Kış ziyaretçisi \\
\hline Gallinula chloropus & Sutavuğu & // & // & Yerli \\
\hline Vanellus gregarius & Sürmeli kızkuşu & $\begin{array}{l}\text { CR-Critically } \\
\text { Endengered (Çok } \\
\text { Tehlikede) }\end{array}$ & // & Yaz ziyaretçisi \\
\hline Turdus pilaris & Tarla ardicı & $\begin{array}{l}\text { LC- Least Concern } \\
\text { (En Az Endişe } \\
\text { Verici) }\end{array}$ & // & Transit göçmen \\
\hline Alauda arvensis & Tarlakuşu & // & // & Yerli \\
\hline Galerida cristata & Tepeli toygar & // & // & Yerli \\
\hline Grus grus & Turna & // & // & Transit göçmen \\
\hline Himantopus himantopus & Uzunbacak & // & // & Yaz ziyaretçisi \\
\hline Streptopelia turtur & Üveyik & // & // & Yaz ziyaretçisi \\
\hline Alcedo atthis & Yalıçapkını & // & // & Yerli \\
\hline Tringa ochropus & Yeşil düdükçün & // & // & Yaz ziyaretçisi \\
\hline Tringa nebularia & Yeşilbacak & // & // & Transit göçmen \\
\hline Anas platyrhynchos & Yeşilbaş & // & // & Yerli \\
\hline Circaetus gallicus & Y1lan kartalı & /1 & $/ /$ & Yaz ziyaretçisi \\
\hline
\end{tabular}

\section{Yazar(lar) Hakkında/About Author(s)}

\section{Osman ÖZER/ osman-ozer@ hotmail.co.uk}

Osman Özer doktorasına Necmettin Erbakan Üniversitesinde devam etmektedir. Yüksek lisansını İzmir Katip Çelebi Üniversitesi'nde tamamladı. 2021 yılı Şubat ayında Nevşehir Hacı Bektaş Veli Üniversitesindeki Otel Lokanta ve İkram Hizmetleri Bölümündeki Öğretim Görevliliğinden ayrıldı. Şu anda Kaski Genel Müdürlüğünde Gastronomi Uzmanı olarak görev yapmaktadır. Çalışma alanları Gastronomi Turizmi, Alternatif Turizmler (Ekoturizm; Av Turizmi, Kuş Gözlemciliği/Ornito Turizm/Avi Turizm) ve Kırsal Turizmdir.

Adres: Mustafa Kemalpaşa Bulvarı No: 186, Kaski Genel Müdürlüğü Kocasinan/KAYSERİ 